\title{
Employing James Bond
}

\section{Introduction}

'There was a creak from M's chair and Bond looked across the table at the man who held a great deal of his affection and all his loyalty and obedience. The grey eyes looked back at him thoughtfully. M took the pipe out of his mouth.' (Diamonds are Forever: 13)

It is common now, within studies of popular culture and organization, to observe that management and work are generally presented negatively, and that this is a form of the 'critique within culture' (Hassard and Holliday, 1998; Rhodes and Parker, 2008; Rhodes and Westwood 2008)'. Cartoons, TV comedies, pop songs, science fiction and other texts have been enrolled as examples of satire, subversion, suspicion and so on, and which show management as evil, organizations as places which crush the soul, and work as something to be escaped from (Parker, 2006). Such an analysis reflects the sort of politicisation of the mundane, of mass culture, which was a common strategy for early cultural studies, particularly that associated with the Birmingham 'Centre for Contemporary Cultural Studies' (CCCS) from the 1970s onwards (Hall and Jefferson, 1976; Willis, 1977; Hall et al, 1980).

Whilst not questioning the general tone of this analysis, it does miss some nuances ${ }^{2}$. A huge number of fictional representations of working lives don't fall easily into this framing, and this is often because they are concerned with occupations that are broadly understood to be socially admirable, and with jobs that are often understood to involve dramatic events. This is not an insubstantial category of media, covering medical dramas, police procedurals, films and TV series about firefighters, mountain or coastal rescue services, lawyers, coroners, forensic psychologists and so on. Much of the time, the drama of the events supports a plot which illustrates the danger or complexity of the task at hand and the bravery and intelligence of those involved. Not always, of course, because there is also an occasional subplot which involves greed, corruption or stupidity by someone who is working for the organization concerned (often a manager), and hence a requirement on the part of the hero to deal with the wrongdoers to achieve the virtuous ends which the organization represents.

These sort of conspiracy subplots are most common in depictions of the police and criminal justice, very common in detective narratives, and perhaps dominant within another related genre, that of the spy or secret agent who must go 'rogue' to achieve their goal. The most famous secret agent in the world is James Bond, the subject of many novels since 1953 onwards, and many films since 1962 onwards. One might hence expect that Bond would be an example of someone who breaks the rules of the organization in order to achieve the goals of the organization but, through a reading of the novels, I instead suggest that the early Bond can be understood in a different way, as an 'organization man' (Whyte, 1956). Bond is rather different from many of the spies and detectives who follow him from the late 1960s onwards, in that he is an obedient employee. He is certainly an autonomous professional, a 
project worker granted a great deal of freedom over his work, but (in the novels) he very rarely makes any explicit or implicit criticism of his employers, and the threats he deals with are all external to the organization. Though Bond does begin to change as the films go on, in the novels and short stories published between 1953 and 1966 he is a model employee.

In the novel Diamonds are Forever, published the same year as The Organization Man, Bond suggests that he couldn't marry a woman because he is already married to a man. 'Name begins with M. I'd have to divorce him before I tried marrying a woman.' (DF: 194) ${ }^{3}$ Bond and his boss are both loyal organization men, often opposed to other evil organizations notably SMERSH and SPECTRE - but most of the time Fleming does not use this as a reason to characterise them as grey flannel 'yes men'. In the novels, learning difficult skills, following rules, being an obedient white collar worker are all presented as elements in a noble vocation. Within this form of thriller 'one knows that eventually, through heroic effort, right will prevail and order will be restored' (Neuse 1982, p. 304). In this paper, I will argue for an understanding of the 1950s Bond as a character who offers what Phil Cohen (1972/1997, p. 94), then a member of the CCCS, called a 'magical resolution' to the tensions between collectivism and individualism which were later to become so stark in representations of spies and detectives, and of the world of work more generally. To make this argument, I will compare the novels to the Bond and other spy films to play up the contrast between the forms of obedience we find in the 1950s Bond - ironically working for an organization which is centrally concerned with conspiracies - with the thoroughgoing scepticism about organizations and their motives which begins in the 1960s and continues to the present day.

This article is a small attempt to historicise fiction about one employee, assuming as I do that the representations of organizations that we find in popular culture are useful ways of examining the changes and fractures in understandings of work and authority. Bond has changed a lot in sixty years. He begins as an obedient organization man, whilst nowadays has become an employee who is often critical of the means and ends of the organization that he works for, even to the extent of going 'rogue' to fulfil his mission. This, it seems to me, tells us something rather important about the ways in which work and organizations were understood in the 1950s, and then how they changed from the late 1960s onwards (Parker, 2002: p. I 40 passim). Given our contemporary schizophrenia about the pleasures and horrors of work, trying to understand an era when organizations and employment were presented in some rather different ways suggests just how difficult it might be now to give our manager the affection, loyalty and obedience that Bond gives to his. I have a strange sense that much contemporary management theory and practice still assumes that it addresses the supposedly gullible and faithful 1950s employee, and that might explain why it so often produces cynicism and withdrawal.

Before I begin, it is worth emphasising that I am not making any claims about the actual practices of espionage organizations in the UK during that period (Hennessy, 2003; Grey, 20I2), though it is clear that Fleming did base much of the content of the novels on his own experiences during the second world war (Chancellor, 2005, p. 26 passim). In contrast, this is a paper about the representation of work within popular culture during a particular 
period, in order that we can understand just how much representations of work have altered over the past half century. I will start by rapidly surveying the intersections between theories of popular culture and ideas about organization, before moving on to discuss the Bond phenomenon and some of the ways in which it has been understood by cultural theorists. I then look at what the novels suggest about understandings of work and organizations in the 1950s before comparing that period to later Bonds. This latter operation necessarily involves thinking through some of the ways in which an understanding of historical context is crucial to thinking through the production and consumption of any text, whether about work and organizations, or anything else. The paper concludes with some thoughts on the impossibility of the Bond novels being written in the present age, a time when the boss has an MBA and the organization's motives are anything but noble.

\section{Popular Culture and the Business School}

The discipline of Management has become separated from the humanities and, more recently, from much of the social sciences too (Colby et al, 20I I; Steyaert et al, 2016). Indeed, it could be argued that the invention and consolidation of any new discipline requires that it distinguishes itself, in terms of methodologies, terminology and social networks, from other disciplines, in order that it can claim novelty and carve out a place within the contemporary university. Concepts from sociology, anthropology, cultural studies and so on have become treated as alien within the business school and, if imported, have often been simplified considerably. It seems to me that this is the case with the concept of 'culture', a central one in much thinking on the humanities and social sciences for two centuries. Until recently, the primary engagement between the disciplines of management and the study of culture was through the study of 'organizational culture' from the 1980s onwards (Parker 2000). Interesting though this work was, it effectively treated culture as if it were a set of shared beliefs held in an organizational container, and largely avoided discussions of how organizational culture might be shaped by a more general anthropological sense of culture. At the other extreme, Hofstede's (I99I) work on national cultures assumed a similarly shared set of values, but this time within the container of the nation state. Further, when the term 'culture' was employed within organization and management theory it was also often assumed that the key respondents were managers, and hence that the lived culture of workers, or of culture more generally, was of little interest. Not exclusively, because there was some work which did take a more anthropological view of culture (Smircich, 1983; Frost et al, 1991; Czarniawska, 1992), but the dominant perspective on culture contained a strong emphasis on managers at work as meaning makers.

Yet this was a view of culture which had already been eclipsed in other parts of the university. For the thinkers associated with CCCS in the 1970s, the study of culture was a search for the ways which dominant, preferred or hegemonic meanings were always in contest with other understandings - those produced and consumed by the working class, women, ethnic minorities and so on (Hall and Jefferson, 1976; Willis, 1977; Hebdige, 1979; Hall et al, 1980). This approach had two important consequences. One was to pay attention 
to the way in which 'readings' of cultural texts should not assume that the meaning of a text is immanent within it, and therefore to be offering readings that are sensitive to difference and contradiction, particularly that which reflects the social divisions of the context from which it originates. The second was to shift attention to texts that were previously considered to be of little interest because they originated within mass or (more positively) popular culture. 'High' cultural texts - literature, classical music, fine art - were eschewed in favour of pop music, magazines, street fashion and so on. This was a shift from an epistemological definition of culture, as Matthew Arnold's 'the best that had been thought and said', to an anthropological definition of culture, as the lived ways of life of a people (Williams, 1976). So far so good, but the institutionalisation of cultural studies from the 1980s onwards tended to produce an account of culture which tended to look at leisure rather than work. The focus was on consumption rather than production, on the spaces and times of leisure, on culture as a category that did not include the economy. The work of popular culture, and the popular culture of work, was falling into a gap between two disciplines.

It was not until the 2000s that writers located in organization and management began to systematically explore the ways in which popular culture represented management, organization and the economy (Hassard and Holliday, 1998; Parker, 2006; Rhodes, 200I, 2004, 2007; Rhodes and Westwood, 2008; Rhodes and Parker, 2008; Bell, 2008, Korczynski, 2014). The dominant assumption in this sort of work has been that cultural representations reflect social tensions, and do not merely ventriloquise shared meanings. However, in searching for various forms of 'critique in culture' there has been a tendency to read popular culture as if its meanings were immanent, and without sufficient attention to the historical specificities of cultural production and consumption within particular eras. To put it simply, the popular culture of work has often been read as if the TV cartoon The Simpsons, the film 9 to 5, or a pop song about working for the weekend all had meanings which could be harvested from the text by an attentive academic. Questions concerning the ambiguity of readings, the responses of different audiences, or historical changes in production and consumption have rarely been addressed, and it is this that I want to do with Bond.

\section{James Bond and Popular Culture}

It seems pretty clear to me that there isn't one Bond. There are twelve novels and two short story collections by lan Fleming, but he died in 1964 and in the following half a century, Bond has appeared in every manifestation of popular culture. The first post-Fleming novel was Colonel Sun, written pseudonymously by Kingsley Amis and published in 1968. Since then, eight other authors have written twenty-nine other authorised novels, or novelisations of films. There are also young Bond novels, three novels about his secretary Moneypenny, many short stories and countless books about the Bond universe, or various aspects of it (such as the 1997 collection of bridge related stories, Your Deal Mr Bond) as well as books on the cars, posters, music and so on. There are also two TV adaptations and one cartoon series, at least six radio adaptations, fifty-two comic strip series in English, and hundreds of comics about Bond and Bond Junior in English, Swedish, Spanish, Japanese, 
Dutch and so on. There are also a lot of video games, as well as board games, jigsaw puzzles, shoes, dolls, trading cards, lunch boxes, alarm clocks, toy cars, guns, briefcases, pyjamas, watches, model kits and rear view spy glasses ${ }^{4}$. All this is before even mentioning the twenty-four 'official' films and two unofficial ones, the oldest and one of the highest grossing film series in cinema history ${ }^{5}$.

Given the multiplicity of cultural texts here, it simply isn't possible to say what Bond represents or means without being specific about which Bond is being referred to. The Bond of lan Fleming's 1953 novel Casino Royale is only distantly related to the Bond of the 2015 film Spectre. There are certain similarities, but the differences are just as instructive, and it is those that my examples will tend to reflect. In an odd sense, we have a sort of longitudinal dataset here - a set of texts spread over nearly sixty years in which certain variables have been kept constant - a secret agent, $M$, sex and violence, and an evil opponent - but their treatment has altered considerably. The secretary who was largely invisible in the early novels becomes a sign of frustrated desire or maternal affection in the later novels and films, and finally a special agent in her own right in the two most recent films. The racial and national stereotypes that are used to characterise the villains in the early books gives way to conspiracies which involve corporations, organized crime and terrorists. SMERSH, the imagined Soviet spy organization, is replaced in the novels by SPECTRE (Special Executive for Counter-intelligence, Terrorism, Revenge and Extortion) from Thunderball (196I) onwards, and from the first film - Doctor No (1962). In the novels, the conspiracies tend to be aimed at Britain, in the films, the targets are often American, or global. Also, and most importantly for this paper, $M$ changes from being the object of Bond's adoration and loyalty, to someone whose motives and character are sometimes in question.

As an illustration of the topics and methods of contemporary cultural studies and the ways that they are employed within the humanities in general, work on Bond is fairly typical. There is a great deal of literature from the 1970s onwards ${ }^{6}$, and it tends to focus on questions of gender, imperialism and consumption, as well as demonstrating certain methodological techniques for addressing cultural texts. In terms of the latter, Umberto Eco's 1979 essay 'Narrative Structures in Fleming' is exemplary in demonstrating what a structuralist semiotic reading of the novels might look like, showing how the stories reprise certain structures, character types and plot arrangements. For Eco, Bond is a text to be analysed in order to demonstrate certain formal techniques, but a great deal of the subsequent writing on Bond is concerned to establish Fleming/Bond's role in the production of problematic representations, not just texts to be analysed. So, we have readings which are concerned with the misogynistic and often violent representations of women; masculine anxieties about technology, the body and power; Fleming's profoundly snobbish accounts of consumption, class and etiquette; the tourist gaze and the beginning of international air travel; the casually racist stereotypes of anyone who isn't white and British; a British Cold War ideology combined with a desperate attempt to recapture the powers of Empire and so on (Cawelti and Rosenberg, 1987; South and Held, 2006; Winder, 2006; Chapman, 2007; Lindner, 2009). 
These analyses are often fascinating, but (Chapman apart) they rarely take Bond's historicity very seriously, and even more rarely consider Bond as an employee. What I want to do is to use my reading of the Bond novels, mostly written in the 1950s, in order to understand how the images of the employee have changed. Putting it simply, I don't think that we would find the 1950s Bond credible anymore, in part because he is such an obedient organization man.

Before I continue, it's worth noting that novels and films are not the same. The intricacies of plot and character that a 200-page novel can build cannot be replicated in a 100-minute film, and the 'action' film genre is defined by certain visual effects and sequences which to some extent also determine plot and character. It is difficult not to present a spectacular Bond in a popular film, a form of cultural production that will avoid banality and stillness. However, I am making an argument in this paper that for certain purposes we can treat the technology of representation (novel or film) as a container for its contents, as what Latour calls an intermediary rather than a mediator (2005, p. 40). This isn't an argument that will always be convincing, but with the Bond corpus we have sixty years of representations of one particular form of work, so it is the changes of representation over time that I want to focus on, by trying to bracket the shaping effects of the different technologies which have been employed to describe Bond's world.

\section{Novels and Work}

'More than a month of paper-work - ticking off his number on stupid dockets, scribbling minutes that got spikier as the weeks passed, and snapping down the telephone when some harmless section officer tried to argue with him. And then his secretary had gone down with the flu and he had been given a silly, and, worse, ugly bitch from the pool who called him 'sir' and spoke to him primly through a mouth of fruit stones. And now it was another Monday morning.' (Thunderball: 2)

It is easy to forget that the Bond novels are about work. Not in the same world weary way as later spy fiction - such as that by Len Deighton, Grahame Greene or John le Carré (Cawelti and Rosenberg, 1987; Denning, 1987, p. 35, 101; Neuse, 1982) - but Bond is clearly working. He arrives at 'that deadly office building near Regent's Park' (CR: 5), 'the gaunt high building' (LD: II) to experience 'the grudging warmth of the hissing gas fire in his office' LD: 35 ). The novels contain realistic signed and dated memos and appendices (CR: 8 passim), and they often begin with paperwork and corridors and offices. We learn that Bond is paid $\ell I 500$ a year, 'the salary of a Principal Officer in the Civil Service', as well as an extra El000 tax free. He goes on missions two or three times a year, and has office hours between ten and six (M: 8). In the novels we meet some of his colleagues - the annoying Armourer, Major Boothroyd; the officious Paymaster Captain Troop; Bill Tanner - the amiable Chief of Staff; and of course M, who we will return to shortly.

One of the ways in which Bond's work is represented as boring is because it is full of women - the 'desirable Miss Moneypenny' (LLD:I2, G: 50), Loelia Ponsonby and Mary Goodnight, his two secretaries and various other unnamed women who 'carry the files, operate the decoders, oversee the paperwork, screen the appointments, and supply the 
canteen services which keep the institution running. Headquarters hums with efficient women...' (Bold, 2009, p. 207). At his Chelsea flat is May Maxwell, his loyal and elderly Scottish housekeeper. Though some of these women are desirable, in a casual way, they are all safe and sensible. For Bond this means boredom, and perhaps even capture, since (as $M$ tells him) women 'hang on your gun-arm' (RL: 105). So, the novels often begin with tedium with 'The Soft Life' (RL: 95) of being stuck at a desk, but the real story begins when Bond is rescued by an exciting mission that usually sees him catching a plane from 'London Airport' to somewhere exotic the next day.

$\mathrm{He}$ is still working then of course, having been given a tough 'job' by $M$. Sometimes he is also pretending to be a member of a different organization, a salesman for 'Universal Exports", the cover employed by the Service. And it is then that he comes up against other organizations, sometimes commercial fronts for the villains, but usually bankrolled by SMERSH and SPECTRE. Both are again represented through mock realist memoranda, and frequent hints at the complex forms of secret conspiracy which underpin their plans. The opening chapters of From Russia with Love show us the SMERSH bureaucracy, the 'cold, brilliant efficiency of the Soviet machine' (LLD: 2I). In Thunderball, SPECTRE announces its intentions by means of a particularly wordy extortion threat that reads like it had been repeatedly edited by company lawyers.

The villains themselves are always physically monstrous, foreign, not sexually normal, cruel and greedy but each has 'exceptional inventive and organizational qualities which help him to acquire immense wealth' (Eco, 1989, p. 40 passim; see also Amis, 1965, p. 65). Crucially, it is their ability to scheme which makes them somehow inhuman, as if such cool rationality were itself enough to provoke suspicion. It seems that 'the size and sophistication of the various criminal organizations mirror the size and sophistication of their criminal conspiracies'. There is often a secret base, 'a space to accommodate not only the ranks of sub-villains, thugs, saboteurs, and assassins, but also the string of torture-chambers, holding cells, laboratories, and nerve centres' (Lindner, 2009, p. 82). Indeed, the sub-villains themselves exemplify the pathology of obedience, with their ant-like dedication to the cause $^{8}$.

Bond's organization is different. The Service values more than mere adherence to the plan. It fights against the cerebral and amoral machinations of the enemy with character bravery, steadfastness and pluck.

'To the typical qualities of the Villain are opposed the Bond characteristics, particularly Loyalty to the Service, Anglo-Saxon Moderation opposed to the excess of the half-breeds, the selection of Discomfort and the acceptance of Sacrifice opposed to the ostentatious Luxury of the enemy, the genial improvisation (Chance) opposed to the cold Planning which it defeats...' (Eco, 2009, p. 43)

Eco's point is echoed by General Vozdvishensky of SMERSH when he considers the motivations of British spies, and the paradox of their excellence.

'Their agents are good. They pay them little money - only a thousand or two thousand roubles a month - but they serve with devotion. [...] They are rarely 
awarded a decoration until they retire. And yet these men and women continue to do this dangerous work. It is curious. It is perhaps the Public School and University tradition. The love of adventure. But still it is odd that they play this game so well, for they are not natural conspirators'. (RL: 42)

Bond, and the rest of them, seem to succeed despite the lack of formal rewards and punishments within the organization. Instead they have character, a form of intrinsic motivation which is more valuable than the explicitly strategised clockwork of the enemy's schemes.

The character of $M$ is instructive here, because it is through $M$ that Bond's relationship to the Service is most clearly revealed. In the books he is generally the unquestioned object of Bond's admiration, a shrewd father figure with a background in the navy who continually plays with his pipe.

'M's face was suddenly friendly. It wasn't friendly often. James Bond felt a quick warmth of affection for this man who had ordered his destiny for so long, but whom he knew so little.' (LT: 27)

Kingley Amis, in his James Bond Dossier parodies Bond's observation of M's 'shrewd, healthy, hard, frosty, damnably clear eyes' (1965, p. 74). Amis tells us that, in the twelve books, M's 'demeanour or voice is described as abrupt, angry (three times), brutal, cold (seven times), curt, dry (five), frosty (two), gruff (seven), hard (three), impatient (seven), irritable (two), moody, severe, sharp (two), short (four), sour (two), stern and testy (five)...' (op cit, p. 75). $M$ is hard to please, and refuses sentimentality, but Bond is always waiting for his call in order to escape from the soft life. He obeys $M$, sometimes cursing and resentful, but always does what he asks. Even when M, in the short story 'For your eyes only' (1960), gives him an obviously off the books assignment to avenge the murder of one of M's friends, Bond obeys.

Obedience to $M$ is a duty, a personal compulsion that reflects 'a certain moral force, an obstinate fidelity to the job - at the command of $M$, always present as a warning' (Eco, 1979/2009, p. 37). Bond does serve the organization, the 'Service', but his allegiance is an intentional stubbornness, a choice to accept and live by certain rules. 'It's a confusing business but if it's one's profession, one does what one's told.' (CR: 59) The novels present a world of obedience to organizations, both good ones and bad ones. The only difference appears to be whether that obedience is chosen for honourable reasons. In You Only Live Twice, after describing the Japanese practice of ON, or 'face', Dikko Henderson, Bond's local guide, says - 'Got it? It's not really as mysterious as it sounds. Much the same routine as operates in big corporations, like ICl or Shell, or in the Services, except with them the ladder stops at the Board of Directors or the Chiefs of Staff.' (LT: 39)

James Chapman suggests that we can understand Bond as a 'middle-grade civil servant' (2007, p. 29, borrowing a line from Kingsley Amis, 1965, p. II). He is a skilled and trained professional who makes calculated choices, and follows an ethic of duty. This supposedly contrasts with the ruthless bureaucrats of SMERSH and SPECTRE, mere tools within 
authority structures. In From Russia with Love, Bond admires the joyful enthusiasm of his Turkish contact Kerim Darko, and contrasts him to the deracinated planners of SMERSH. Perhaps, he thinks, 'the right man was better than the right machine' (RL: I54).

Fleming's Bond is conventional, and the political views he expresses are those of a Daily Mail middle Englander railing against the 'permissive mushiness of Welfare England' (Landa, 2006, p. 9I). In You Only Live Twice (1964) Tiger Tanaka, a Japanese secret service agent, drunkenly rants about the Suez crisis of 1956, and then goes on to complain to Bond that -

'your governments have shown themselves successively incapable of ruling and have handed over the country to the trade unions, who appear to be dedicated to the principle of doing less and less work for more money. This feather-bedding, this shirking of an honest day's work, is sapping at ever-increasing speed the moral fibre of the British, a quality the world once so much admired.' (LT: 80)

Bond roars with laughter, and suggests that Tanaka write a letter to The Times. In the books, Bond is no freethinker, no 1930s dilettante secret agent driven by ideas of justice, but neither is he a sociopath who dispenses judgement. Kingsley Amis contrasts him to a contemporaneous literary creation, Mickey Spillane's Mike Hammer, a violent American PI. In One Lonely Night (195I) Hammer muses 'I lived to kill because my soul was a hardened thing that revelled in the thought of taking the blood of the bastards who made murder their business... I was the evil that opposed other evil, leaving the good and the meek in the middle to live and inherit the earth!' (quoted in Amis, 1965, p. 29). Most of the time, Bond simply lacks such imagination, leaving it to the villains, in this case Blofeld, to characterise him best of all.

'You are a common thug, a blunt instrument wielded by dolts in high places. Having done what you are told to do, out of some mistaken idea of duty or patriotism, you satisfy your brutish instincts with alcohol, nicotine and sex while waiting to be dispatched on the next misbegotten foray' (LT: 192).

Bond does (very occasionally) reflect, in Casino Royale (p. 134 passim) for example, but such introspection is rare. After some mournful bed-bound self-doubt following the bruising encounter with Le Chiffre, he is chastised by his colleague Mathis and told - 'don't let me down and become human yourself. We would lose such a wonderful machine.' (CR: I39). The culmination of this first novel, with the death of his treacherous lover at the hands of SMERSH, clearly marks the end of his doubts about his occupation. It is a position he often enough restates, in Moonraker, for example - 'There must be no regrets. No false sentiment. He must play the role which she expected of him. The tough man of the world. The Secret Agent. The man who was only a silhouette.' (M: 246)

\section{Bond After the Novels}

Fifty years of films, and all the other cultural products, tend to conceal the novels nowadays, and in any case the Bond we know has gradually changed, becoming more an action hero and less a self-effacing public servant. Moneypenny - with the cups and saucers kept in her 
office - flirts more and more desperately as the films go on (Brabazon, 2009; Stock, 2009), though she eventually becomes a secret agent in her own right. $M$ becomes an increasingly 'fuddy-duddy Establishment figure', less threatening and more blustering (Bennett and Woollacott, 1987, p. 34). His office is staged with framed paintings of tall sailing ships, a model of a ship in a glass cabinet, replica cannons, busts of historical figures, thick green curtains, a globe, and old telescope and antique maps (Stock, 2009, p. 252). When M becomes a woman in 1995, her office is marked by a 90s modernism - black leather chairs and vertical blinds, as well as a much more combative relationship with Bond.

These markers of social change are interesting, but for the argument in this paper the most important difference between the novels and the films is the extent to which Bond finds himself at odds with the Service itself. He comes late to this position though, because cops and detectives had often become outlaws and vigilantes from the early 1970s onwards (Sparks, 1996, p. 353; Chapman, 2007, p. 129, 21 I). Beginning perhaps with Dirty Harry (197I), the dominant motif is that the law enforcer has to break the rules of the organization in order to bring justice to the lawless. Dirty Harry was followed by four sequels, there have been six Death Wish films since the first in 1974, four Lethal Weapon films beginning in 1987, five Die Hard films from 1988 onwards, four Jason Bourne films from 2002, and so on. These are anti-organization films, narratives in which conspiracies mean that the institutions of law and justice cannot be trusted, that bosses let you down and nothing is what it seems.

'Many of these films seem to imply a failure of politics as such: there is a vacuum, into which the hero must step, motivated not by profession, duty or patriotism but rather by his purely personal and familial bonds, or by a still more basic instinct for survival...' (Sparks, 1996, p. 356)

Though Bond did threaten resignation in the 1969 On Her Majesty's Secret Service (an echo of some musings in the novel), it is not until The Living Daylights of 1987 that he refuses to kill someone, before eventually going 'rogue' in the 1989 License to Kill. Clearly getting a taste for his new-found independence, in Die Another Day (2002), he is suspended, then reinstated, with the same happening in SPECTRE (2015).

So the film Bond, slowly and hesitantly, begins to become the 'lawless hero' who raises some very contemporary questions about the relationship between 'law' and 'justice', between 'institutions' and 'freedom' (Forster, 2006, p. 126). Yet his roots are in a different time, and seemingly reflect some rather different assumptions. The Bond books occupy an unusual period, one in which the activities of the business organization seem to have been regarded as relatively benign. This contrasts with representations from before the Second World War, a world of films like Metropolis and Modern Times, of organizational dystopias like The Castle and Brave New World and sparkling eyed criminals who steal from the rich (Parker, 2002, p. I36-I40; 20I2, p. II 3 passim). As Penzler puts it -

'The impoverished multitudes blamed the actions of Wall Street brokers, bankers, big businessmen and factory owners for their plight, so what could be more 
attractive than to see someone break into their posh apartments and crack their safes, or nick the diamond necklaces from the fat necks of their bloated wives?' (2008, p. xi)

Using Eric Amber and Graham Greene's spy fiction from the 1930s as his illustrations, Michael Denning shows how business was often used as the origin of the problem that the amateur sleuth needs to solve - 'Cator and Bliss', 'Pan-Eurasian Petroleum' and the 'Eurasian Credit Trust' for Ambler, and 'Midland Steel' and the 'Beneditch Colliery Company' for Greene (1987, p. 74 passim). By the 1950s, Fleming appears to be writing during a moment in which such criticisms had become rather muted, a world in which the organization was a backdrop for romance in films, or the source of material wealth and scientific expertise (Parker, 2002, p. 140-2). Work might be boring, and there might be stupid bosses and irritating colleagues, but the legitimacy of the organization itself was not in doubt. The system had worked, and the armies and factories of the allies had defeated the fiendish schemes of the enemy.

Denning suggests, borrowing some ideas from Frederic Jameson, that it isn't until the 1970s that capitalism once again becomes 'figurable' in the person of the multinational corporation. At that point, 'capitalism becomes objectified and dramatized as an actor and as a subject of history with an allegorical intensity and simplicity that had not been the case since the 1930s.' (1987, p. 74). Simultaneously, representations of work then become much more ambivalent, with threats just as likely to come from within the organization as outside it. The spy novels from this later period, such as those by John le Carré, Len Deighton, and Grahame Greene again, become 'cover stories of white-collar work, of the organization man' (1987, p. I I7). He quotes Greene, speaking of his 1978 novel The Human Factor.

'My ambition after the war was to write a novel of espionage free from the conventions of violence, which has not, in spite of James Bond, been a feature of the British Secret Service. I wanted to present the Service unromantically as a way of life, men going daily to the office to earn their pensions, the background much like any other profession - whether the bank clerk or the business director - an undangerous routine, and within each character the more important private life' (Denning, 1987. p. 130)

The novel itself is a story of betrayal, of secrecy and paranoia within the organization. Within the spy genre, these themes become dominant from the 1970s onwards, with le Carré's George Smiley series being perhaps the best example (Cawelti and Rosenberg, 1987, p. 156 passim). This is what Neuse, following Palmer (1979), calls the transition from 'thriller' to 'negative thriller'. If the protagonist in the former overcomes obstacles to maintain the organizational status quo, then the latter recognises that 'the hero's own organizational system is an impediment to the resolution of the conspiracy' (I982, p. 297). Bond's loyalty to M's clear blue eyes really does begin to look anachronistic compared to 'the deeper, more critical tale where the real enemy is the organization itself, the organization that never keeps faith, the organization that betrays its own men' (Denning, 1987, p. 140). This, it seems to me, is the world that we live in now, a world in which 
management and organization are understood to be the generators of conspiracy, not the solution to them.

\section{Figuring Work in Popular Culture}

Drew Moniot, in 1976, outlined a broadly functionalist explanation for the first decade of Bond films, suggesting that what he called 'formula' culture has similarities with other rituals which allow for a structure for excitement, suspense and release. The highly choreographed arrangement of events in the films allows for a temporary and fantastic resolution of the frustrations and tensions of everyday life (1976, p. 29). So far this looks like an argument based on assumptions about social integration, but Moniot then adds something rather more interesting. He notes that the films also concern themselves with the 'Corporate State', with the crime syndicates which hide behind the facades of factory and office complexes Goldfinger's 'Auric Enterprises' (1964), the 'Osato Chemical Corporation' in You Only Live Twice (1967), the 'Institute of Physiological Research' in On Her Majesty's Secret Service (1969) and the Willard Whyte empire in Diamonds are Forever (197I). In the first film, Dr No (1962), the bauxite mine is, according to Julius No himself, 'but a microcosm of the organization, syndicate, call it what you will' which aims at 'ultimate control, complete, all powerful, of the world... and beyond.' Behind the corporate-industrial, Moniot suggests, lies evil and greed (op cit, p. 30). And the Bond of the films too works for an organization like this, Universal Exports, with its unassuming exterior, and an interior of desks, files, secretaries, bureaucracy and a boss figure in his office. 'The structure of both organizations is that of the Corporate State. The difference lies not in the structure of the system but rather in the ultimate objectives and the means employed in attaining those objectives.' (op cit, p. $3 \mathrm{I}$ ). Moniot concludes that Bond's job is to get rid of pathological characters, not to change the system itself. It's a message is a comforting and conservative one, that 'the existing social system could still be cleaned up rather than being discarded.' (op cit, p. 32).

Moniot's argument is interesting, and echoes much that has been written about images of management in popular. It's also interesting because of what it misses out - the novels. In fact, there are very few named corporations in the novels themselves, but more and more in the films. As well as Moniot's examples we can add 'Stromberg Shipping' in the 1977 Spy Who Loved Me, 'Zorin Industries' in View to a Kill (1985), the 'Carver Media Group Network' in Tomorrow Never Dies (1997), 'King Industries' in The World is not Enough (1999) and so on. Chapman is unconvinced by Moniot's presentation of the anti-corporate Bond, suggesting that the idea of the individual against a machine like organization was not new in the 1960s, and mentions Chaplin's Modern Times (1936) as an example (2007, p. 97). Chapman is right of course, but his example comes from an earlier period. What Moniot's analysis of the films allows us to distinguish is that the Bond novels come from a very particular period, one in which the machine organization (SMERSH, SPECTRE) was seen to be an external threat, whilst the 'home' organization was a force for good. It is not until the 1960s films that the corporation begins to be 'figured' as a potential threat in the Bond Universe at all, and even then it can be countered by the pluck and daring of one loyal man supported by a professional team. 
The other part of Moniot's analysis is the one that suggests that the films supply a fantastic resolution to the tensions of everyday life. His suggestions largely stay at the level of the individual gratifications that might be gained from being a spectator of a Bond formula film, but a more social analysis of cultural texts is perfectly possible too. Phil Cohen, in an early paper that prefigured some key ideas from the Birmingham Centre for Contemporary Cultural Studies, suggested that youth subcultures offered magical resolutions to the contradictions of the everyday.

'It seems to me that the latent function of subculture is this: to express and resolve, albeit "magically", the contradictions that remain hidden in the parent culture' (1972/1997, p. 94)

Cohen suggested that the procession of subcultures represented transformations of 'the basic problematic or contradiction which is inserted in the subculture by the parent culture' (op cit). Culture here becomes understood as a fractured imaginative response to structural tensions and contradictions in the social. This is a development of the anthropologist Claude Levi-Strauss's definition of myth in pre-industrial societies, as a form of thought which 'progresses from the awareness of oppositions towards their resolution' (1963, p. 224). It is latent, in the sense that the participants in such imaginings do not necessarily connect their fantasies with the social conditions that generated them. But then, by definition, the meaning of fantasy cannot be manifest. If its cause and aim were clear to all who produced and consumed it, it would no longer be fantastic. So Cohen's point is something to do with a certain sort of fantasy, but not a fantasy in terms of its common sense of ungrounded escapism, a castle in the air. Rather than running away, this was a fantasy that took everyday materials and re-worked them into some sort of account that helped resolve them. Not solve them, because that would require social structural change, but to re-imagine hidden injuries, to construct an account which echoed with the anxieties of the time.

The word 'magical' is important here, in the sense that it suggests a method for overcoming obstacles or contradictions by deploying powers and devices not commonly found in everyday experience. Fleming himself referred to his books as 'fairy tales for grown-ups' (Chancellor, 2005, p. 100). Michael Denning (also a onetime member of CCCS) suggests that this element of the fantastic is a way in which we might understand the attraction of the spy genre as a whole. It is a 'cover story', a form of ideology which serves to glamourize ordinary white collar work.

'...the magical nature of the secret agent functions both as a wish-fulfillment, returning agency to a largely meaningless kind of work, and as an explanation of that work, a recognition of one's own lack of power.' (1987, p. 35)

Denning wants us to think about the people who read spy fiction, and he concludes that it is largely the professional classes. So this is white collar workers reading about white collar work, or what Julian Symons has called a 'perfect pipe-dream figure for organization man' (in Denning, 1987, p. 93). Spy fiction matters because - 
'...its focus on the world of espionage does not necessarily make it about spies. Rather the intelligence community serves as a shadowy figure for the social world of late capitalism where the opacities that surround human agency are cut through by projecting an essentially magical figure, the secret agent.' (Denning, 1987, p. 29)

The early British spies - Sapper's Bulldog Drummond, Buchan's Richard Hannay and so on were gentlemen amateurs, bored with the routine of office and club. They escaped to spying as plucky improvisers who would set right particular wrongs. Bond, on the other hand, is a professional. He is trained by the organization, is subject to authority and orders, and suffers all the petty indignities that any office worker experiences. The only sense in which he continues an earlier amateur tradition is in his consumption habits, for particular cigarettes, suits, food, travel and so on. He is, as Landa suggests (2006) an 'aristocratic bourgeois', a character with aristocratic tastes and a bourgeois lifestyle.

The Bond of the novels is a splendid example of Cohen's magical resolution, in the sense of a character who is riven with contradictions (Cawelti and Rosenberg, 1987, p. 154). His character allows the professional to display amateur traits, to be cool and calculating at the same time as being passionately loyal and patriotic. For the male heterosexual reader, Bond can be a recognisable white collar worker who idly fancies his secretary, but at the same time a dangerous and sexually predatory rake who travels the world. Bond is both an obedient employee who does what he is told and also an autonomous adventurer. The resolution is even captured in the phrase 'licensed to kill'. Bond is licensed, by some legitimate authority. He is not allowed to kill anyone, under any circumstances, and so is not a mere murderer, a psychopath who enjoys 'taking the blood of the bastards who made murder their business'. His killings are 'jobs', clearly justified in memos, licensed as necessary by a man with clear blue eyes. David Frum, writing about the cultural contradictions of the 1950s, suggests that 'Bond is simultaneously an organization man and an individualist. Above all, he can do wrong for a greater good without losing his moral bearings' (cited in Forster, 2006, p. 124). The 00 section dispenses with legal procedure, allows Bond to kill people when other private citizens can't, and at the same time allows him ethical immunity. The law is somehow suspended, placed in a state of exception which allows it to both exist and disappear at the same time.

The Bond novels are not a simple vehicle for the communication of shared meanings, but a symptom of the anxieties of a particular time, particularly anxieties about work.

'These stories permit the recognition of contradictions at the same time as they establish conventional ways of managing and resolving those contradictions. Thus a study of popular narratives has a purchase which the study of other recreations may not - for these narratives are not only of the culture but are about the culture.'

(Denning, 1987, p. 24)

The novels came out at a time when a world war was only twenty years in the past, in a period when Britain's empire was crumbling, its industries were collapsing, and its 'great power' status was becoming a bitter joke (Winder, 2006, p. 102). In a nice irony, after the 
Suez debacle, the then PM Anthony Eden decided to have a holiday and ended up staying in 'Goldeneye', Fleming's home in Jamaica. He resigned a few months after his return, a symbol of the post-Imperial despair and longing that Fleming had crystallised in the magical figure of the secret agent. Bond's social attitudes, his casual racism and superhuman ability to defeat external threats can be contrasted with a Britain that was becoming an irrelevance. 'Bond in fact became in the 1960s pretty much the only British national capable of damaging anybody at all.' (Winder, 2006, p. 196)

\section{Conclusion: Bond Now}

Kingsley Amis was a fan of popular narratives, particularly science fiction. He was keen to defend Bond against the many who, from the late 1950s onwards, were accusing Fleming of writing fictions which were immoral, and even sadistic. The reviewers have never much liked Bond. Amis accepts Bond's vices, but also points to his virtues. 'Some things are regarded as good: loyalty, fortitude, a sense of responsibility, a readiness to regard one's safety, even one's life, as less important than the major interests of one's organization and one's country.' (Amis, 1965, p. 85). This is a remarkably traditional set of characteristics for a killer, indeed a list which (perhaps sacrifice of life excepted) many professional employees would be happy to endorse as necessary for the performance of their occupation. Amis clearly finds Bond's 'concern to do his job, devotion to $M$ and trust in M's judgment, personal obstinacy, plus finally the vaguest patriotism' much more attractive than the 'anguished cynicism and torpid cynicism respectively of Messrs le Carré and Deighton' (1965, p. 94).

However, at the time of writing. Bond is not doing well. The current incumbent, Daniel Craig, has reportedly said that he would 'rather slash [his] wrists' than make a fifth Bond film. ${ }^{9}$ The franchise continues to make money, though less than it used to, because cinema fantasy is now dominated by superheroes, conspiracy thrillers and science fiction. Bond can only become a contemporary action hero if he rejects being an organization man, if he refuses to obey $M$ and believe in the rightness of the British Secret Service. Bond's gender and ethnicity are even more troubling for 'a character who was a cardboard throwback even in the 1960s... a wall-eyed, traumatised thug, a protagonist who is two-dimensional precisely because he is empty inside' (Penny, 2015, p. 3 I, see also Sparks 1996) ${ }^{10}$. Yet, whatever the critics might say, and have been saying for half a century, the potential for magical resolution is still there -

'The dilemma of James Bond is a pantomime version of the dilemma facing most men who grew up watching the films and wondering what it would be like to be that guy, whom everybody seems to love not in spite of the awful things he does but because of them. In real life, anyone who behaved even slightly like James Bond would be ostracised, arrested, or both.' (Penny, 20I5, p. 3I)

As she knows, Laurie Penny is writing sixty years after the first Bond novel and her argument, like mine, is an attempt to historicise Bond. It seems to me that if we want to understand any cultural text, we need to situate it within particular moments of production 
and reception. If we try to set aside the technological differences between novels and films, then it becomes clear in the texts themselves that the meaning of Bond has changed, and likely that it will continue to change. As Pierre Macherey rather beautifully observes, understanding culture involves understanding the conditions of its production and also its history - 'everything which has been collected on it, become attached to it - like shells on a rock by the seashore forming a whole incrustation.' (in Woollocott, 2009, p. II7). So reading Bond now is different to reading Bond then, a historicity that needs to be remembered in the analysis of any cultural text, whether about organizations and management or anything else.

Ours is a world in which corporations and governments are assumed to lie, in which conspiracy and secrecy go hand in hand, and anxiety and insecurity are common experiences of working life (Parker 2016). Representations of work are always shadowed by such assumptions, with even 'good' occupations - doctors, the police - often being entangled in Machiavellian plots. The Bond of the novels reminds us of a time when formal organizations might have been imagined to be sites for some sort of authenticity and salvation, even those organizations that were centrally involved in conspiracies. The characters and plots show us that the Service will save us from the evil schemers of SMERSH and SPECTRE, and that men at desks can also be men of action. It's a moment that is difficult to recover now, when even Bond goes rogue and doesn't shave on occasion ". George Smiley's 'Circus' captures the labyrinthine gothic of contemporary organizations rather more effectively. Indeed, his author, John le Carré, makes this into a timeless diagnosis of the human condition.

'I think all of us live partly in a clandestine situation. In relation to our bosses, our families, our wives, our children, we frequently affect attitudes to which we subscribe perhaps intellectually but not emotionally. We hardly know ourselves - nine-tenths of ourselves are below the level of the water (...) So the figure of the spy does seem to me to be almost infinitely capable of exploitation for purposes of articulating all sorts of submerged things in our society' (In Bruccolli and Baughman, 2004, p. 36)

Fleming, in Bond's mock obituary at the end of You Only Live Twice, allows M to allude to the 'series of popular books... written by a personal friend and former colleague' as 'high-flown and romanticized caricatures of episodes in the career of an outstanding public servant' (LT: 202). It's a self-effacing dismissal of the popular, the romantic, as if culture had very little to say about the sorts of lives that people actually live in organizations. I don't agree. I think that we can learn much from popular books, and popular culture generally, and in the case of Bond, what we catch is a glimpse into a moment in British understandings of the organization man and the redemptive possibilities of work. The relationship between Bond and $M$, between loyal employee and gruff but kindly father figure, is simply no longer credible, and this is a conclusion which is both realistic and tragic.

\section{References}

Amis, K. (1965) The James Bond Dossier. London: Jonathan Cape. 
Bell, E. (2008) Reading Management and Organization in Film. Basingstoke: Palgrave Macmillan.

Bennett, T., Woollacott, J. ( 1987) Bond and Beyond: The Political Career of a Popular Hero. London: Routledge.

Bold, C. (2009) '"Under the very skirts of Britannia": Re-reading women in the James Bond novels.' In Lindner, C (ed) The James Bond Phenomenon: A Critical Reader. Manchester: Manchester University Press, 205-219.

Brabazon, T. (2009) 'Britain's last line of defence: Miss Moneypenny and the desperations of filmic feminism.' In Lindner, C (ed) The James Bond Phenomenon: A Critical Reader. Manchester: Manchester University Press, 238-250.

Bruccoli, M. and Baughman, J. (eds) (2004) Conversations with John le Carré. Jackson, MS: University Press of Mississippi.

Cawelti, J. and Rosenberg, B. (1987) The Spy Story. Chicago: University of Chicago Press. Chancellor, H. (2005) James Bond: The Man and His World. London: John Murray. Chapman, J. (2007) License to Thrill: A Cultural History of the James Bond Films. London: I.B. Tauris.

Cohen, P. (1997) 'Subcultural Conflict and Working Class Community'. In Gelder, K. and Thornton, S. (eds) The Subcultures Reader. London: Routledge, 90-99.

Colby, A., Ehrlich, T., Sullivan, W. and Dolle, J. (20II) Rethinking Undergraduate Business Education. San Francisco: Jossey-Bass.

Czarniawska, B. (1992) Exploring Complex Organizations: A Cultural Perspective. London: Sage. Denning, M. ( 1987$)$ Cover Stories. Narrative and Ideology in the British Spy Thriller. London: Routledge and Kegan Paul.

Eco, U. (1979) 'Narrative Structures in Fleming.' Reprinted in Lindner, C (ed) (2009) The James Bond Phenomenon: A Critical Reader. Manchester: Manchester University Press, 34-55.

Forster, G. (2006) '’Just a stupid policeman": Bond and the rule of law.' In South, J. and Held, J. (eds) (2006) Questions are Forever: James Bond and Philosophy. Chicago, IL: Open Court, I2I-I37.

Frost, P., Moore, L., Louis, M., Lundberg, C. and Martin J. (eds) (199I) Reframing Organizational Culture. Newbury Park, CA: Sage.

Grey, C. (2012) Decoding Organization. Cambridge: Cambridge University Press.

Hall, S., and Jefferson, T., (1976), (eds.), Resistance Through Rituals. London: Hutchinson. Hall, S., Hobson, D., Lowe, A. and Willis, P. (eds) (1980) Culture, media, language: working papers in cultural studies, 1972-1979. London: Routledge. 
Hassard, J. and Holliday, R. (eds) (1998) Organization - Representation. London: Sage.

Hebdige, D. (1979) Subculture. The Meaning of Style. London: Methuen.

Hennessy, P.. (2003) The Secret State: Whitehall and the Cold War. London: Penguin.

Hofstede, G., (1991), Culture and Organisations: The Software of the Mind. New York: McGraw Hill.

Korczynski, M (2014), Songs of the Factory: Pop Music, Culture and Resistance. Ithaca, NY:

Cornell University Press.

Land, C., Loren, S. and Metelmann, J. (2014) 'Rogue Logics: Organization in the Grey Zone' Organization Studies 35/2: 233-253.

Landa, I. (2006) 'James Bond: A Nietzechean for the Cold War.' In South, J. and Held, J. (eds) (2006) Questions are Forever: James Bond and Philosophy. Chicago, IL: Open Court, 7993.

Latour, B. (2005) Reassembling the Social. Oxford: Oxford University Press.

Levi-Strauss, C. (1963) Structural Anthropology. London: Penguin.

Lindner, C. (ed) (2009) The James Bond Phenomenon: A Critical Reader. Manchester:

Manchester University Press.

Linstead, S. and Grafton Small, R. (1992) 'On Reading Organizational Culture' Organization Studies 13/3: 331 - 355.

Moniot, D. (1976) 'James Bond and America in the Sixties' Journal of the University Film Association XXVIII/3: 25-33.

Neuse, S. (1982) 'Bureaucratic Malaise in the Modern Spy Novel: Deighton, Greene and Le Carré' Public Administration 60: 293-306.

Palmer, J. (1979) Thrillers: Genesis and Structure of a Popular Genre. New York: St. Martin's Press.

Parker, M. (2000) Organizational Culture and Identity. London: Sage.

Parker, M. (2002) Against Management. Oxford: Polity.

Parker, M. (2006) 'The Counter Culture of Organization: Towards a Cultural Studies of Representations of Work' Consumption, Markets and Culture 9/I: I-I5.

Parker, M. (2012) Alternative Business: Outlaws, Crime and Culture. London: Routledge.

Parker, M. (2016) 'Secret Societies: Intimations of Organization' Organization Studies 37/I: 99-II3. 
Penny, L. (2015) 'Pity the boys raised to admire James Bond' New Statesman $5^{\text {th }}$ November: 31.

Penzler, O. (2008) 'Foreword', in Penzler, O. (ed) Pulp Fiction: The Villains. London: Quercus.

Rhodes, C. (200I) 'D'Oh: The Simpsons, Popular Culture and the Organizational Carnival', Journal of Management Inquiry. 10(4): 374-383.

Rhodes, C. (2004) 'Utopia in Popular Management Writing and the Music of Bruce Springsteen: Do You Believe in the Promised Land?', Consumption, Markets and Culture. 7(I): I-20.

Rhodes, C. (2007) Outside the Gates of Eden: Utopia and Work in Rock Music, Group and Organization Management, 32(I): 22-49.

Rhodes, C. and Parker, M. (2008) 'Images of Organizing in Popular Culture' Organization 15/5: 627-637.

Rhodes, C. and Westwood, R. (2008) Critical Representations of Work and Organization in Popular Culture. London: Routledge.

Smircich, L. (1983), 'Concepts of Culture and Organisational Analysis', Administrative Science Quarterly, 28: 339-359.

South, J. and Held, J. (eds) (2006) Questions are Forever: James Bond and Philosophy. Chicago, IL: Open Court.

Sparks, R. (1996) 'Masculinity and Heroism in the Hollywood Blockbuster' British Journal of Criminology 36/3: 348-360.

Steyaert, C., Beyes, T., and Parker, M. (eds) (2016) The Companion to Reinventing Management Education. London: Routledge.

Stock, P. (2009) 'Dial 'M' for metonym: Universal Exports, M's office space and empire.' In Lindner, C. (ed) The James Bond Phenomenon: A Critical Reader. Manchester: Manchester University Press, 25I-267.

Whyte, W. H. (1956) The Organisation Man. New York: Simon and Schuster.

Williams, R. (1976) Keywords. London: Fontana.

Willis, P. (1977), Learning to Labour. Farnborough: Saxon House.

Winder, S. (2006) The Man Who Saved Britain. A Personal Journey into the Disturbing World of James Bond. London: Picador.

Woollacott, J. (2009) 'The James Bond Films: Conditions of Production'. In Lindner, C. (ed) The James Bond Phenomenon: A Critical Reader. Manchester: Manchester University Press, II 7 135. 
' Thanks to James Chapman, for wise advice, as well as the reviewers for this journal, and Chris Grey, Carl Rhodes and Warren Smith for comments on an earlier version.

${ }^{2}$ Another nuance is the positive representation of belonging and criminal organizations, see Parker 2012.

${ }^{3}$ The Bond novels I have cited are all the 2004 Penguin Classics editions. The key is as follows, CR - Casino Royale (1953), DF - Diamonds are Forever (1956), DN - Dr No ( 1957), G - Goldfinger (1959), LLD - Live and Let Die (1954), LT - You Only Live Twice (1964), M Moonraker (1955), RL - From Russia with Love (1957), T - Thunderball (196I).

${ }^{4}$ Moniot quotes someone calling this the 'Bondanza', and gives more examples of early merchandise (1976: 26). See also Chapman 2007: 92.

${ }^{5}$ And this is also without mentioning the way that Bond explicitly or implicitly functions as a reference point or counter point in other literary spy fictions, such as that by Frederick Forsyth, Desmond Bagley and Len Deighton; other spy films and TV series such as the Harry Palmer, George Smiley or Jason Bourne; parodies such as the Flint, Matt Helm, Austin Powers and Johnny English film series; TV shows such as The Avengers, The Man from U.N.C.L.E. and so on (see Moniot 1976).

${ }^{6}$ Much of it being characterised by weak Bond related puns for titles, subheadings or concluding sentences.

7 Changed to the 'Transworld Consortium' in The Man with the Golden Gun (1965). Peter Hennessy notes that there was a secret committee charged to investigate the possibility and consequences of nuclear attack on Britain in 1950. It was titled the 'Imports Research Committee' (2003: xix).

${ }^{8}$ For some thoughts on the HR implications of being a henchman for a supervillain, see Winder 2006: 232, and several scenes in the 1997 parody Austin Powers: International Man of Mystery.

${ }^{9}$ http://www.bbc.co.uk/news/entertainment-arts-34603708, accessed 4/4/I6.

${ }^{10}$ Oddly, Fleming himself referred to Bond as a 'cardboard booby' (Chancellor 2005: I0I).

"Land et al (20I4) make the convincing argument that the 'rogue' (their example is the trader) is a figure who marks the grey zone within which behavior is no longer either good or bad. Adapting their argument, I suggest that the appearance of the rogue marks a legitimation crisis for the organization, so the rogue lawman brings the law into question. 